\title{
Elevational treeline and forest line dynamics in Norwegian mountain areas $-\mathbf{a}$ review
}

\author{
Anders Bryn $(\mathbb{D} \cdot$ Kerstin Potthoff $\mathbb{C}$
}

Received: 5 October 2017 / Accepted: 14 June 2018/Published online: 22 June 2018

(C) The Author(s) 2018

\begin{abstract}
Purpose Treelines and forest lines (TFLs) have received growing interest in recent decades, due to their potential role as indicators of climate change. However, the understanding of TFL dynamics is challenged by the complex interactions of factors that control TFLs. The review aims to provide an overview over the trends in the elevational dynamics of TFLs in Norway since the beginning of the 20th century, to identify main challenges to explain temporal and spatial patterns in TFL dynamics, and to identify important domains for future research.

Method A systematic search was performed using international and Norwegian search engines for peer-

Electronic supplementary material The online version of this article (https://doi.org/10.1007/s10980-018-0670-8) contains supplementary material, which is available to authorized users.
\end{abstract}

\section{A. Bryn}

Natural History Museum, University of Oslo, Blindern, P.O. Box 1172, 0318 Oslo, Norway

e-mail: anders.bryn@nhm.uio.no; anders.bryn@nibio.no

A. Bryn

Norwegian Institute of Bioeconomy Research, P.O. Box 115, 1431 Ås, Norway

\section{K. Potthoff $(\bowtie)$}

Department of Geography, University of Bergen,

P.O. Box 7802, 5020 Bergen, Norway

e-mail: kerstin.potthoff@uib.no reviewed articles, scientific reports, and $\mathrm{MA}$ and $\mathrm{PhD}$ theses concerning TFL changes.

Results Most articles indicate TFL rise, but with high variability. Single factors that have an impact on TFL dynamics are well understood, but knowledge gaps exist with regard to interactions and feedbacks, especially those leading to distributional time lags. Extracting the most relevant factors for TFL changes, especially with regard to climate versus land-use changes, requires more research.

Conclusions Existing data on TFL dynamics provide a broad overview of past and current changes, but estimations of reliable TFL changes for Norway as a whole is impossible. The main challenges in future empirically-based predictions of TFLs are to understand causes of time lags, separate effects of contemporary processes, and make progress on the impacts of feedback and interactions. Remapping needs to be continued, but combined with both the establishment of representative TFL monitoring sites and field experiments.

Keywords Climate change $\cdot$ Disturbance $\cdot$ Mountain birch $\cdot$ Range changes $\cdot$ Time lag $\cdot$ Treeline 


\section{Introduction}

Changes in geographical range limits of species and their underlying causes is a key issue in ecology and biogeography (Gaston 2009). Alongside species, geographical range changes of, for example, plant functional types (PFTs), vegetation types (VTs), or treeline and forest lines (TFLs) are enduring topics of research (Holtmeier 2009; Wullschleger et al. 2016). Scientific interest in TFL changes has grown considerably in recent decades (see e.g. Harsch et al. 2009; Körner 2012; and references therein). Although influenced by varying processes that result in distributional time lags, climatic TFLs are considered potential indicators of climate change because they reflect processes that occur at different spatial and temporal scales (Smith et al. 2009; Hofgaard et al. 2013).

Prospects of future climate change assumed to result in tree and forest range expansion, as well as forest cover changes caused by land-use changes have led to an increased focus on issues ranging from empirical data gathering, explaining temporal and spatial patterns of TFLs, to projective distribution modelling (Case and Duncan 2014; Sharma et al. 2014; Jacob et al. 2015; Rydsaa et al. 2015). Overviews of trends in elevational shifts in TFLs are available on a broad range of scales (Gehrig-Fasel et al. 2007; Harsch et al. 2009; Wehn et al. 2012; Ameztegui et al. 2016). Whereas broad-scale studies allow for identification of general trends in TFL shifts, detailed explanations of change patterns are, for example, challenged by the inclusion of different TFL species. By contrast, local-scale studies commonly include only one dominant species, yet due to their small spatial coverage their representativeness is geographically restricted. To our knowledge, no studies to date have covered a large geographical area in which TFLs are dominated by one species only (but see Lloyd's (2005) study on Alaskan treelines).

TFLs in Norway have two characteristics that make them interesting for a review. First, among the countries spanned by the Scandinavian mountain chain that are dominated by mountain birch (Betula pubescens ssp. czerepanovii) (Broll et al. 2007; Öberg and Kullman 2012; Odland 2015), only in Norway is mountain birch dominant as a TFL species, although it is a constituent species in the TFLs in northern Finland and Sweden. According to the standard topographic map of Norway, the empirical forest line (i.e. actually observed) currently rises to almost $1300 \mathrm{~m}$ a.s.l. in south-central Norway (i.e. the central part of South Norway) (see Fig. 1 for forest lines interpolated from standard topographic maps). Second, Norway has a long history of land use in mountainous areas. The mountains have been used for, among other purposes, seasonal farming and semi-domestic reindeer grazing, both of which have influenced the elevation of the TFL in much of Norway since their introduction in the late Bronze Age and the 16th century, respectively (Bryn and Daugstad 2001; Hansen and Olsen 2004). This kind of land-use legacy occurs in populated mountain areas worldwide (Price 2007) and challenges the understanding of the impacts of climatic changes on TFLs.

The aim of this review is to provide a synthesis of empirical elevational changes in TFLs in Norway and to explain the spatial and temporal patterns in the changes, although we acknowledge that also changes in latitudinal TFLs have been reported (Hofgaard et al. 2013). Our focus is on changes occurring in the current and last century, since it was not until the beginning of the 20th century that precise mapping of TFLs gained any momentum in Norway. In order to summarize current knowledge and to make suggestions for future research, we address the following questions:

1. What trends do the available data on elevational changes in TFLs show? What is the quality of the data and for what purposes can they be used?

2. What are the main challenges to explaining temporal and spatial patterns in elevational changes in TFLs?

3. What type of data and knowledge are needed to improve future empirically-based predictions of changes in TFLs?

\section{Terminology and definitions}

A wide variety of terms and definitions are used to denote the transitions from tree- and forest-covered areas to open areas (Holtmeier 2009). Although exact definitions may differ, the majority of the literature reviewed for this article distinguishes between treelines and forest lines. The terms treeline or tree limit (and similar Norwegian terms) are used to denote the highest elevational occurrence of upright trees, but the heights of such trees differ between, for example, trees 
Fig. 1 Empirical forest lines in Norway today. The model is based on interpolation (kriging) of point samples representing the highest forest locations throughout Norway. Point data $(\mathrm{N}=1064)$ were sourced from the national forest map of Norway (Norwegian Mapping Authority 2007), data represent the highest occurrences of forest locations using block statistics (ArcMap version 9.3.1) with a block size of $20 \times 20 \mathrm{~km}$. For details on data and methods see Online Appendix 1

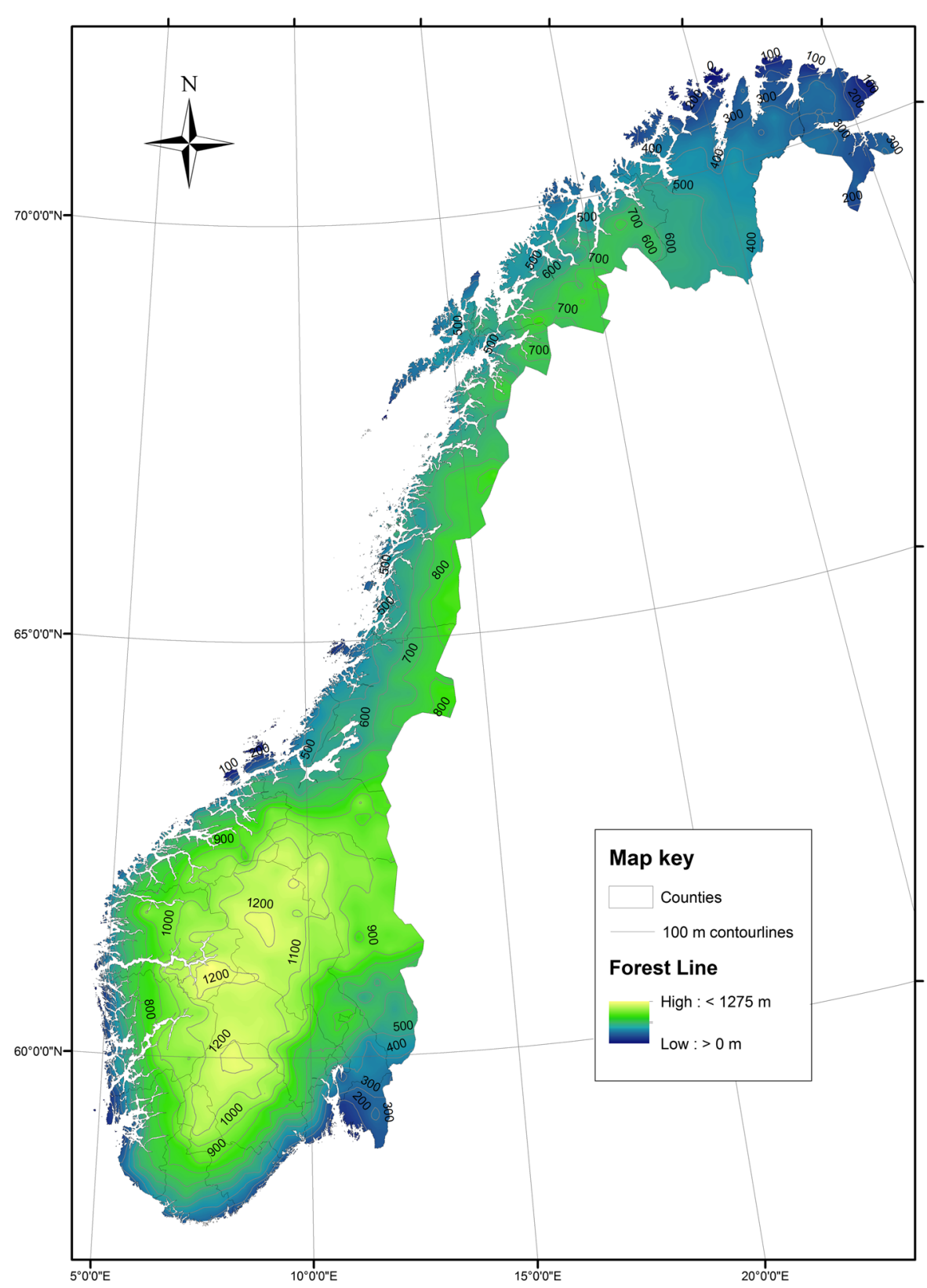

that are higher than a man or are $1,(\geq) 2,(>) 2.5$, and $3 \mathrm{~m}$ in height. Forest line, forest limit, or timberline are used to denote the highest occurrence of forests, but forest definitions differ with regard to, for example, distance between trees, canopy cover, and patch size. Single forest stands are commonly included in the determination of highest forest line elevations. Some authors also use the term species limit, referring to the highest occurrence of a given tree species.
In this review we follow the reviewed literature and distinguish between treelines reflecting the highest occurrence of upright trees and forest lines denoting the highest occurrence of forests and single forest stands. We acknowledge that changes in treelines occur to some extent independently of changes in forest lines and vice versa, since TFLs of the same species do not necessarily respond in a similar way to, for example, climate change. Nevertheless, the fact that TFLs constitute physiognomic height limits 
correlated with the same environmental factors (i.e. climate, disturbances and edaphic and topographic conditions) means it is logical to treat them in one review. We follow White and Pickett's (1985, p. 7) definition of disturbances as 'any relatively discrete event that disrupts the structure of an ecosystem, community, or population, and changes resource availability or the physical environment'. By contrast, disturbance regimes reflect spatial and temporal dynamics of disturbances over a longer period. In origin, disturbances may be abiotic (e.g. snow avalanches), biotic (e.g. caterpillar attacks), human (e.g. domestic grazing), or a combination of these three types.

\section{Methods}

We used the search engine ISI WEB of Science to identify all relevant and available peer-reviewed papers on elevational changes in TFLs in Norway (search terms, in all combinations: Norway, tree, forest, line, limit, expansion, regrowth, reforestation, forest regeneration; latest search 10 March 2015). Moreover, we considered all scientific reports and master's and doctoral theses referred to by the aforementioned papers or found through the Norwegian search engine BIBSYS Ask (search terms: skoggrense, tregrense, gjengroing, skogendring; latest search 10 March 2015). We extracted all publications that (1) provided information on elevational changes in TFLs in Norway, (2) reported changes in the spatial
Fig. 2 Treeline and forest line (TFL) changes and five-year average summer temperature and precipitation development for the regions with registered TFL changes. Both temperature (in degrees Celsius) and precipitation (in per cent) are given as deviations from the last normal period (1961-1990). Data on temperature and precipitation were provided by the Norwegian Meteorological Institute. All TFL locations for which the year and elevation of first measurement and remeasurement were available are included. Due to differences in definitions of TFLs and different methods used, data can only be used to extract general trends. Unless noted otherwise, single location data are provided. In cases where average data for larger regions were not provided by the authors of the publications, they were calculated as far as possible. North Norway: Krossdalen, Sollia, Sollitind, Olderbekken, Store Mauken, Alapen, Rostafjellet (FL) and Store Mauken, Alapen (TL); south-central Norway: Knaushøgda (3 locations) and Valdres (4 locations) (FL), Knaushøgda (2 locations) (TL); south-east Norway (The FL change data for south-east Norway depicted in Fig. 3 gives the average data provided by Aas (1969). Since Aas excluded an unknown number of single locations when calculating his average data, the average shown in this figure (Fig. 2), which is based on all of his 25 single locations, differs from the one shown in Fig. 3): 25 FL locations and 36 TL locations (see Fig. 3 for locations)

extent of forest cover in the TFL zone, and (3) discussed factors that have an impact on TFL elevation.

We identified 17 publications containing information on TFL changes (see Online Appendix 2 for references and Fig. 3 for geographical location of all elevational change data on TFLs). Two publications contain overlapping data, leaving 16 publications with unique data. Three of the 16 publications additionally report changes in the spatial extent of forest cover. In addition to the 16 publications, a further 2 only give

Table 1 Changes in the spatial extent of forest cover in the TFL zone

\begin{tabular}{|c|c|c|c|c|}
\hline Where & $\begin{array}{l}\text { Time } \\
\text { frame }\end{array}$ & $\begin{array}{l}\text { Study } \\
\text { area size }\end{array}$ & Results & Reference \\
\hline $\begin{array}{l}\text { Seasonal farms in } \\
\text { Central Norway }\end{array}$ & $\begin{array}{r}1960 \mathrm{~s}- \\
1990 \mathrm{~s}\end{array}$ & - & $\begin{array}{l}\text { Early woodland succession on } 60 \% \text { of previously open semi- } \\
\text { natural grasslands within a } 30 \text {-year period } \\
\text { Woods on } 70 \% \text { of previously open heathland after } 25 \text { years }\end{array}$ & $\begin{array}{l}\text { Olsson et al. } \\
\text { (2000) }\end{array}$ \\
\hline Western Norway & $1972-1993$ & c. $14 \mathrm{~km}^{2}$ & Forest increased by nearly $47 \%$ & $\begin{array}{l}\text { Engum } \\
\quad(2006)\end{array}$ \\
\hline South-east Norway & 1959-2001 & $161.5 \mathrm{~km}^{2}$ & Increase in mountain birch forest by c. $10 \%$ & Bryn (2008) \\
\hline Western Norway & 1965-2004 & - & Forest cover increased by $7 \%$ & $\begin{array}{r}\text { Rannow } \\
(2013)\end{array}$ \\
\hline $\begin{array}{l}\text { Western Norwegian } \\
\text { mountain valley }\end{array}$ & $1947-2008$ & $3.2 \mathrm{~km}^{2}$ & Increase in mountain birch forest by c. $25 \%$ & $\begin{array}{r}\text { Potthoff } \\
(2017)\end{array}$ \\
\hline
\end{tabular}

Due to differences in definitions of forest and different methods used, data can only be used to extract general trends 


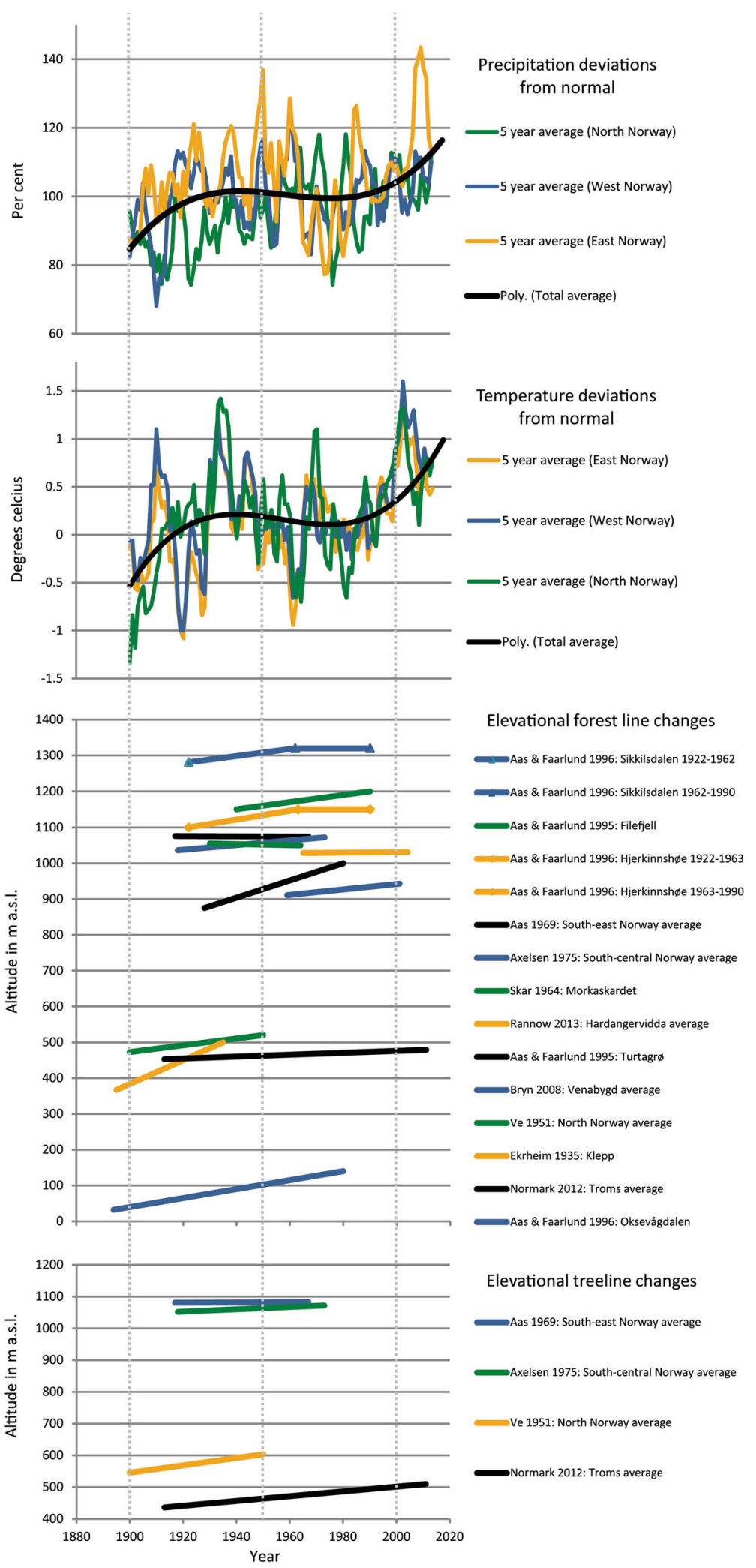




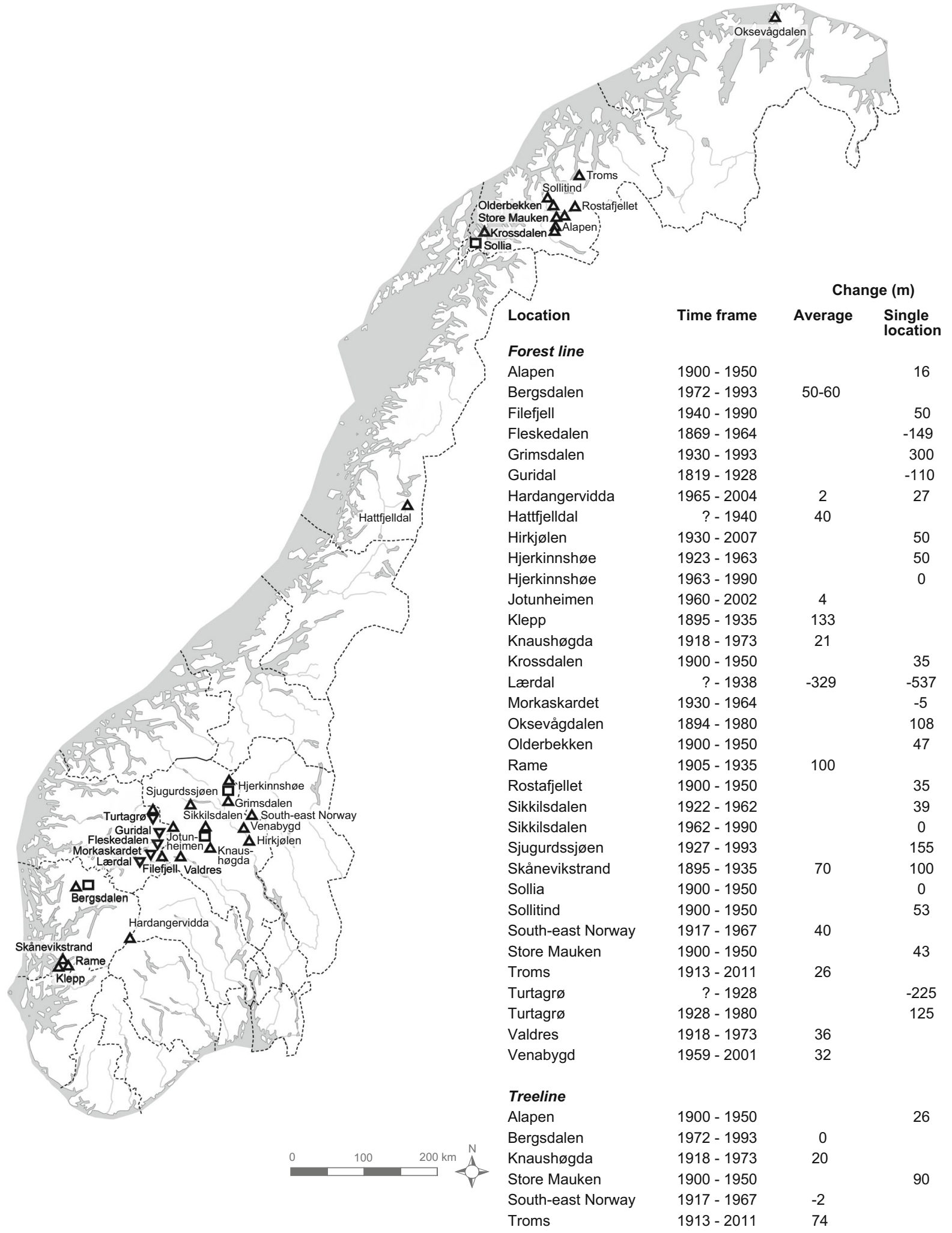


4Fig. 3 Elevational treeline and forest line change based on 16 studies presenting unique data (see Online Appendix 2 for references). Upwards pointing triangles symbolize treeline and forest line rise, downwards pointing triangles regression and squares stability. All data are included, including those not relating to measured change (see Online Appendix 2). Due to differences in definitions of TFLs and different methods used, the data can only be used to extract general trends. Insofar as they are available, single location data are included. Average data have been used in cases where authors have not provided single location data. The following locations reflect average values, since single locations could not be depicted due to being located too closely: Jotunheimen: average data for 7 locations (Wehn et al. 2012); Knaushøgda—single location data for 2 TLs and 3 FLs called Knaushøgda (Axelsen 1975); Lærdal—single location data for 8 locations (Ve 1940); Valdres-single location data for 4 locations identified by Axelsen (1975), except for Knaushøgda

information about changes in the spatial extent of forest cover (see Table 1 for references and geographical locations). All 18 publications discuss factors that influence TFL elevation. In addition, we found 28 publications that identify factors that have an impact on TFL elevation, but do not link them to measured elevational changes. Most of these publications are cited in the section 'Explanations for treeline and forest line changes'. However, since the publications are rather numerous and provide similar information we did not include all of them in our review (see Online Appendix 3 for references not cited in this article). We supplied the section 'The role of climate versus land use' with a targeted search for climate and land-use data.

The 16 publications that provide unique data on TFL changes vary greatly in the amount and quality of the data they report (see Online Appendix 2 and the section 'Data quality' below). Moreover, the definitions of TFLs differ among the publications (see the section 'Terminology and definitions' for definitions used). This variability rendered a detailed comparison of studies impossible. Hence, we focused on identifying the main trends in the data and only compared different areas in Norway or different periods in a general manner. The study by Aas (1969) is prominent with regard to the number of TFL change data collected (61 locations) and has been used to gain an insight into local variability in TFLs. Moreover, for 100 single locations for which information about the year of remeasurement and the elevation of first measurement and remeasurement was provided, an accuracy assessment was made on the basis of methods used and the precision of the original location names (see Bryn and Potthoff 2017 for details).

The literature survey revealed two questionnaire surveys that had been conducted among foresters, farmers in mountain areas, and those working with geographic mapping of Norway, concerning TFL changes and reasons for the changes. The surveys were carried out in 1923 and at the end of the 1930s, respectively (Hesselberg and Birkeland 1940; Ve 1951). Raw data from the first survey were published in Tidsskrift for Skogbruk (1924-1927). Although the degree of detail in the responses varied, all responses contained information about the name of the person who provided the information, the name of the municipality in which the observation was made, information about the tree species, whether a rise, a regression, or stability in TFL had occurred, reasons for the changes, and whether boreal forest had been replaced by deciduous forest. In most cases, only one observation for each municipality was provided, but some respondents provided information for different parts of a municipality, and in total there were 421 observations. Data from the second survey are available as county data (Hesselberg and Birkeland 1940). For each county, the data contain a number of observations of rise or stability in the FL (197 observations in total) and in cases of a rise in FL, also observations of whether a temperature increase had influenced the change. We summed up the change observations from the first survey as county data and added accounts of regression and stability to make the surveys comparable (see Fig. 5 for a county-based comparison of the data). Although the first survey asked about TL changes and the second survey about FL changes, we treated both types of changes as TFL changes because no information on definitions was provided. Moreover, from Ve's (1951) presentation of the results of the first survey as FL changes, it is probable that the terms were used interchangeably in the surveys.

A number of limitations need to be taken into account when interpreting the survey data:

(1) Reported changes are based on the respondents' personal impressions. However, due to the respondents' occupations, we consider their impressions rather reliable.

(2) The 1923 survey covered 'protection forest' (i.e. forest protecting, for example, settlements 


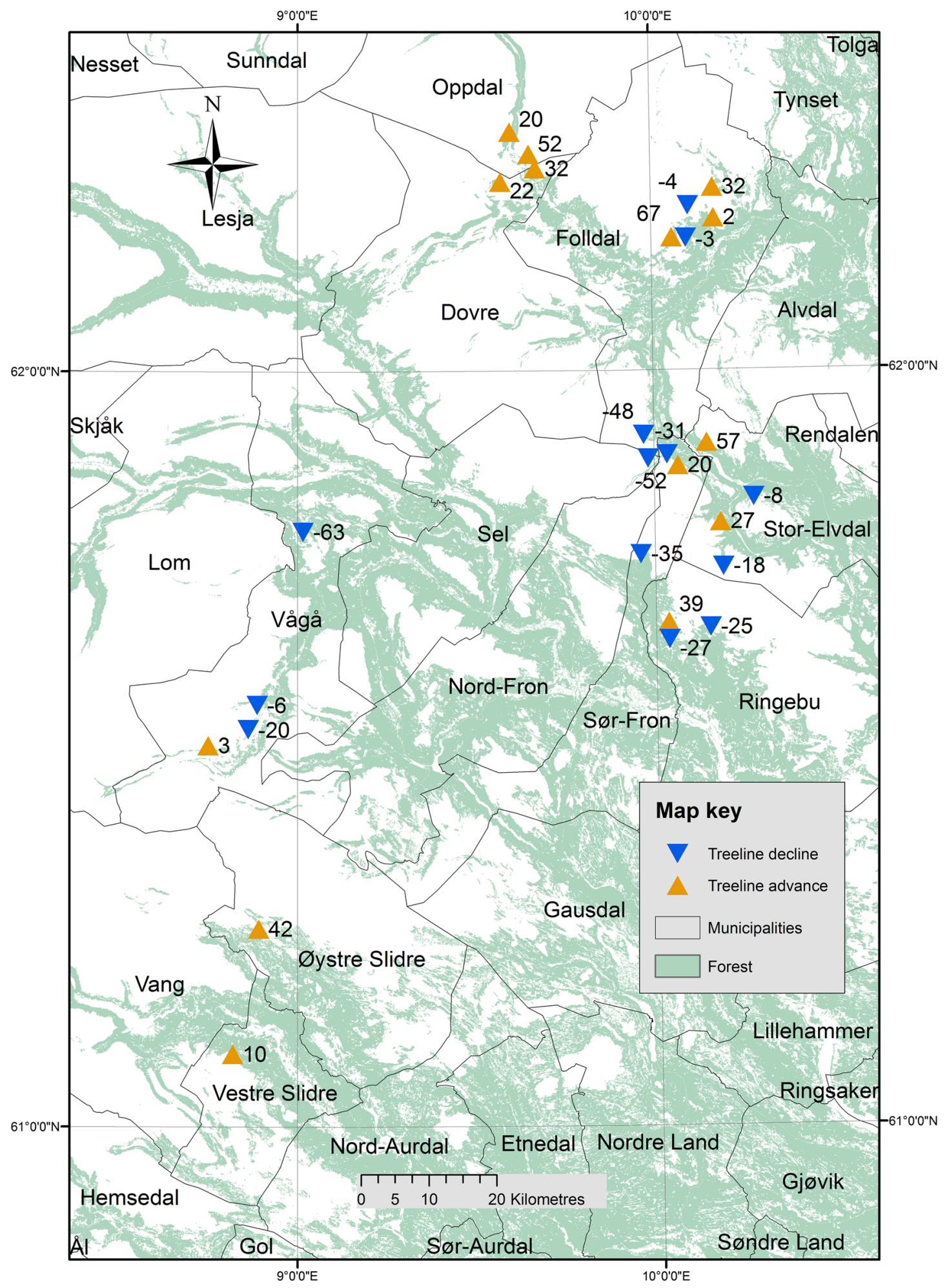

Fig. 4 Local variability in elevational treeline (a) and forest line (b) changes in south-east Norway (see Fig. 3 for location); data from Aas (1969) 


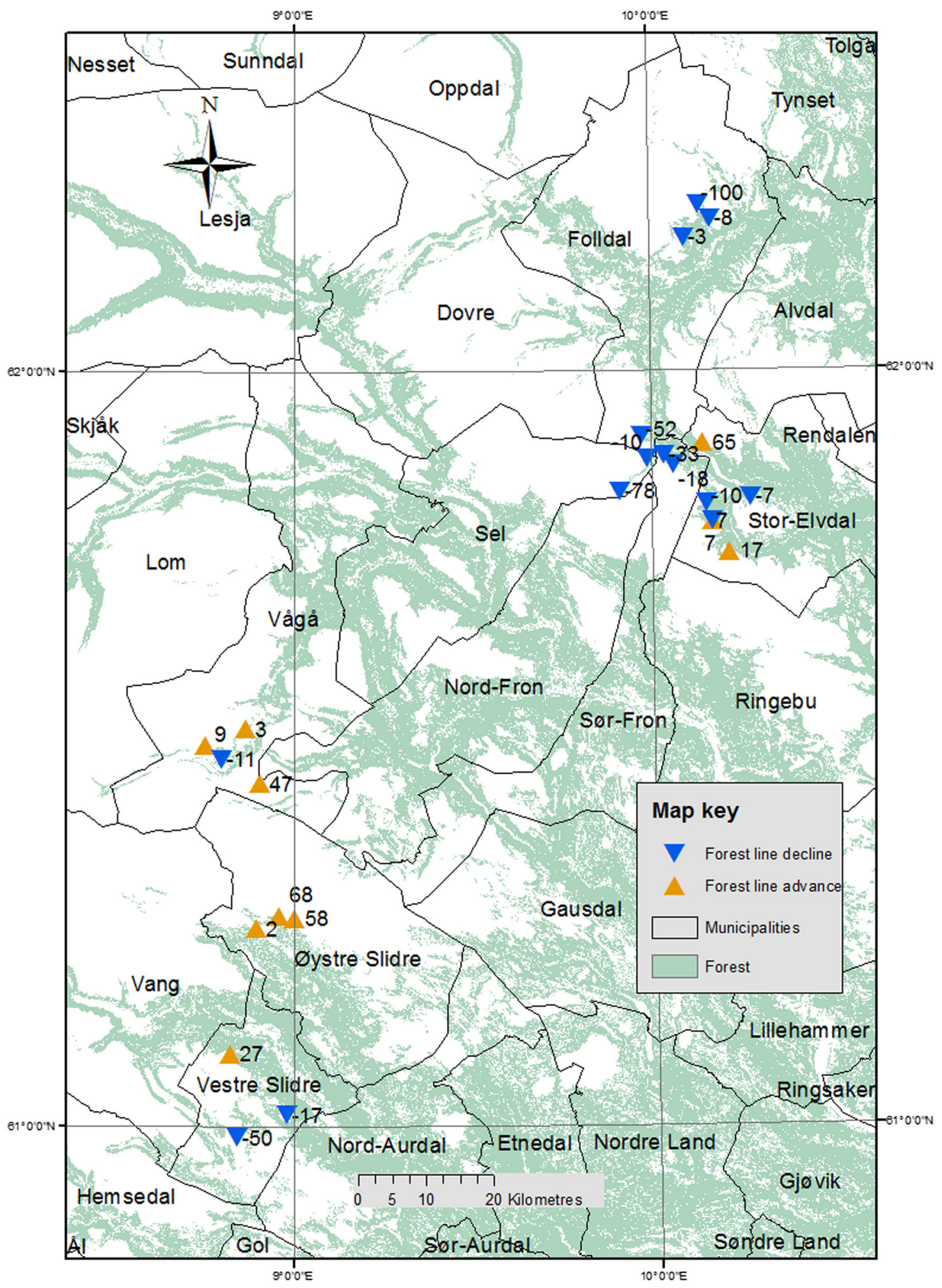

Fig. 4 continued 
against natural disasters, and forest located at the margins of forest growth), hence not only elevational changes were included.

(3) Foresters were likely to have focused on productive forest and might have tended to report changes in occurrences of coniferous trees.

(4) The data are geographically skewed, since some areas are poorly covered and the counties differ in size.

We did not to exclude any data from the 1923 survey, despite limitations (2) and (3), since we could not be certain that we could remove all records that did not concern elevational changes in birch TFLs. Despite all restrictions and although the survey data are not comparable with change data for single locations or larger regions provided in Fig. 3, we consider that the data can be used to extract some general trends and to add to the understanding of main changes in TFLs.

\section{Results}

A short history of Norwegian treeline and forest line research

It was not until the beginning of the 20th century that precise mapping of treelines and forest lines gained any momentum, starting up with the work of Hanna Resvoll-Holmsen (1914) in south-east Norway. The first broader overviews of changes in the position of the forest lines were based on questionnaire surveys (Hesselberg and Birkeland 1940; Ve 1951). The first data on elevational changes were available in 1930 (Ve 1930), and Aas (1969) was the first researcher to remap and present a systematic measurement of changes in TFLs in Norway. He revisited sites where Hanna Resvoll-Holmsen had previously registered the elevation of mountain birch TFLs (Resvoll-Holmsen 1918). Aas's work has provided the most comprehensive data set of in situ remeasurements of the highest TFL locations in Norway to date.

Besides mapping TFL elevations, many of the early studies provided information on factors that have an impact on TFL elevation (e.g. Ve 1930; Ekrheim 1935; Ve 1940; Aas and Faarlund 1996). Since these studies were conducted on the basis of researchers travelling long distances in the field, they resulted in rather descriptive publications. By contrast, recent studies have commonly been based on local-scale empirical or experimental studies. For example, ecologists have tried to identify the optimum locations for mountain birch establishment and growth (Löffler et al. 2004; Rössler et al. 2008; Hofgaard et al. 2009). Other scholars have performed local grazing experiments in fenced areas (Speed et al. 2010) or used opentop chambers for climate impact studies (Hofgaard et al. 2010). Access to time series of aerial photographs and satellite images has provided an additional source for measurements of elevational changes in forest lines and for an assessment of the spatial extent of forest line changes (Bryn 2008; Wehn et al. 2012; Rannow 2013; Potthoff 2017).

Treeline and forest line variability in time and space

Average values reflecting larger regions and singlepoint measurements reflecting local growth conditions since the beginning of the 1900s and until the 2000s show a general trend of rising TFLs, independent of elevation (Fig. 2). Additionally, an increase in forest coverage in the TFL zone in Norway has been reported for that period (Table 1).

The only accounts of forest-line regression date from the early 20th century, with the exception of one relating to Morkaskardet (1930-1964), located in inner Western Norway (Fig. 3). In addition, the remapping of TL changes in south-east Norway by Aas (1969) shows a regression of the average TL elevation (Fig. 3). These data indicate temporal and regional differences in TFL changes. However, change data from the beginning of the 20th century are scarce and geographically more poorly distributed than later measurements (Fig. 3). In addition, the majority of the TFL observations documenting a regression are single location data.

Regression also occurs in areas for which, on average, the data show a rise in TFLs, thus reflecting local variability (Fig. 4a, b) and resulting in rather low rates of annual change (see Normark 2012; Wehn et al. 2012; Rannow 2013, Table 2). Thus, the accounts of regression from the beginning of the 20th century might only report part of a local variability, not a general regional trend.

Additional insights into early TFL changes were gained from the results of the questionnaire surveys. 
Table 2 Annual rates of forest line changes

\begin{tabular}{llll}
\hline Annual rate of change $(\mathrm{m})$ & & Time frame & Location \\
\hline Average & Single location & & Bergsdalen \\
\hline 2.62 & 1 & $1972-1993$ & Filefjell \\
& & $1940-1990$ & Hardangervidda \\
0.06 & 0.68 & $1965-2004$ & Hirkjølen \\
& 0.65 & $1930-2007$ & Hjerkinnshøe \\
& 1.25 & $1923-1963$ & Hjerkinnshøe \\
0.1 & 0 & $1963-1990$ & Jotunheimen \\
& & $1960-2002$ & Oksevågdalen \\
& 1.26 & $1894-1980$ & Sikkilsdalen \\
0.65 & 0.98 & $1922-1962$ & Sikkilsdalen \\
0.8 & & $1962-1990$ & South-central Norway \\
0.27 & & $1918-1973$ & South-east Norway \\
& & $1917-1967$ & Troms \\
0.76 & & $1913-2011$ & Turtagrø \\
\hline
\end{tabular}

Only remeasurements in situ of exact locations and changes based on aerial photographs or satellite images are included. Due to differences in definitions of FLs and different methods used, data can only be used to extract general trends. See Fig. 3 for locations and Online Appendix 2 for references

${ }^{a}$ Average data for seven average values in Wehn et al. (2012)

${ }^{b}$ Average data for seven single locations in Axelsen (1975)

The data seem to confirm that TFL regressions were more common in the early 1900s than later. In 1923, about one-third of the respondents reported a rise in TFLs, one-third a regression, and one-third stability, indicating a general trend of rather stable TFLs. Accounts of TFL rise increased from 1923 until the end of the 1930s for all counties (Fig. 5). Moreover, the data confirm the occurrence of regional differences.

Data quality

The quality of the elevation change data was influenced by the measurement accuracy at the original location and the accuracy of the remeasurements. Thus, knowledge about methods and related uncertainties that were used to identify the original locations and to resample them is needed in order to assess the uncertainty of any measured change. The authors of the publications reviewed for this article used a variety of methods to study TFL changes: for $69 \%$ of the remeasured locations their measurements were based on in situ remeasurement, $15 \%$ on measurements of the elevational difference between old and young mountain birch forest or between empirical and climatic forest lines, $12 \%$ on maps, aerial photographs and satellite images, $3 \%$ on oral information, and $1 \%$ on other sources (see Online Appendix 2 for locations; additionally, all single point measurements by Aas (1969) are included, see Bryn and Potthoff (2017) for locations).

Only two of the authors who used in situ remeasurements provide information about the methods used to collect the original measurements (63 locations), and one of them informs about the instrument used for measuring elevation. Two other authors give a quantitative assessment of the accuracy of the remeasurements (4 locations). Of those authors who used elevational measurements of old and young forests, one provides information about the instruments used (1 location), but none assesses the error of the measurements. Two of the authors who used maps, aerial photographs, and satellite images to collect elevation change data provide a qualitative error 


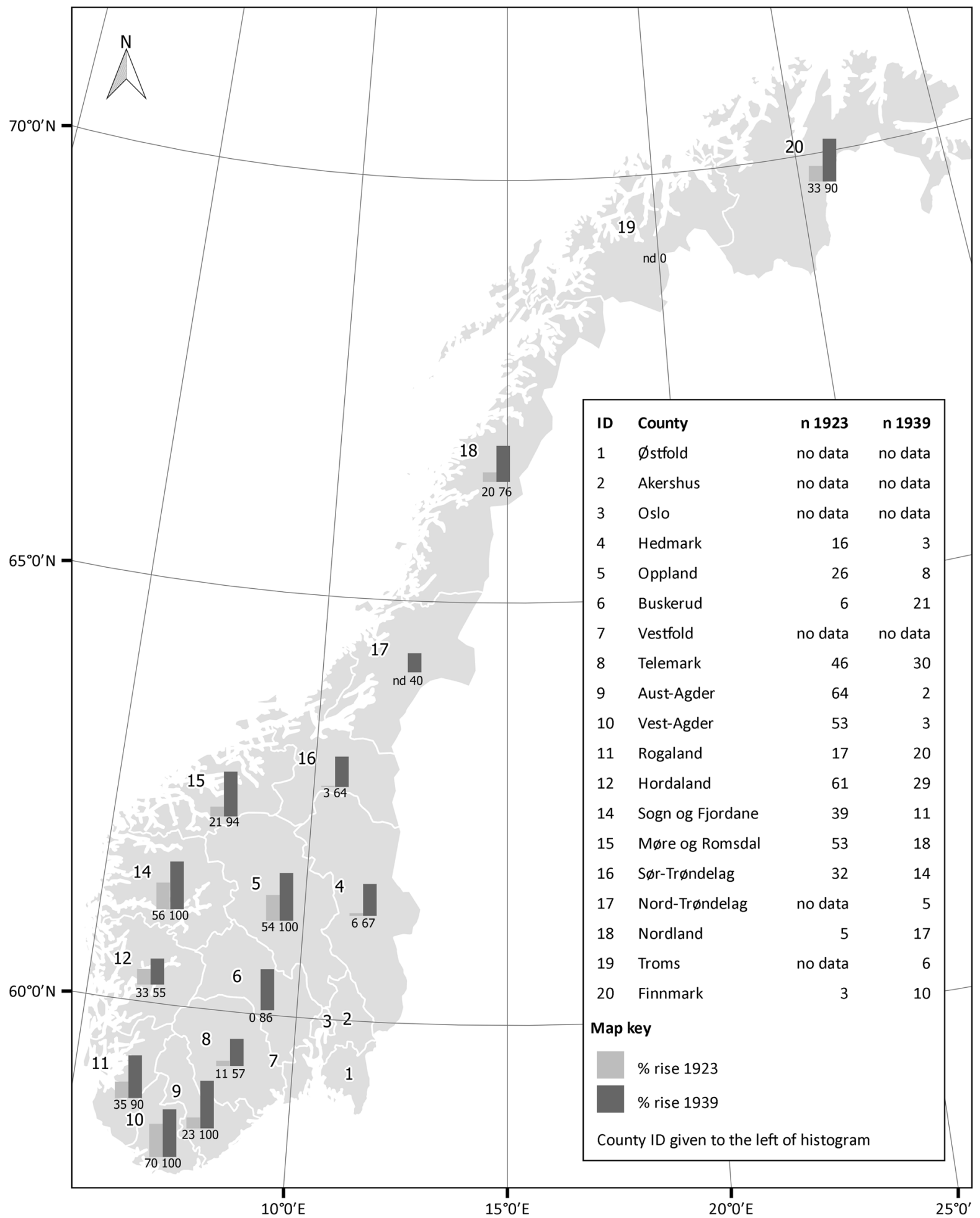

Fig. 5 TFL rise reported in two questionnaire surveys carried out in 1923 and the end of the 1930s in per cent of respondents per county 
assessment (3 locations), and one author gives a quantitative assessment (1 location).

Such scarce information about data quality renders both an estimation of uncertainty for different periods and regions and a systematic estimation of the relative errors in the results following the use of the different methods impossible. For the 100 single locations (see Bryn and Potthoff 2017 for a map) for which we carried out an accuracy assessment, we in general assumed that in situ measurements and comparisons of empirical and climatic forest lines using a barometer would give intermediate elevational precision ( $\pm 10 \mathrm{~m}$ a.s.1.) (81 locations) (Bryn and Potthoff 2017). Additionally, we assumed that comparison of old and young forests, map comparisons, and comparison with an old photo would result in a low precision ( $\pm 25 \mathrm{~m}$ a.s.1.) (19 locations). None of the measurements had high elevational precision $( \pm 5 \mathrm{~m}$ a.s.l.), reflecting standard GPS quality.

Moreover, all methods that rely on remeasuring a location on the basis of place names will, in addition to the precision of the measurement instruments and methods used, be influenced by the precision of the place names, such as the name of a seasonal farmstead as opposed to the name given to a large slope. The resulting combined uncertainty in aspect and elevation ranges between 160 and $5200 \mathrm{~m}$ (average $1113 \mathrm{~m}$ ) for the 100 single locations accessed (see Bryn and Potthoff 2017 for details).

Explanations for treeline and forest line changes

\section{Climate, disturbances, and edaphic and topographic conditions}

Understanding the variability in TFLs through time and space requires knowledge of the factors that regulate their dynamic position. Our review shows that as early as the 1910s, Helland (1912) connected the growth of trees to a minimum mean temperature for the months of June, July, August, and September (i.e. the tetratherm). The relevance of temperature as an important factor controlling TFL elevation has been underlined in several other early studies (e.g. Ve 1930; Ekrheim 1935; Ve 1940). Odland (1996) shows a correlation between mountain birch forest limits and both the mean maximum temperature of July (isotherm $15.8^{\circ} \mathrm{C}$ ) and the mean maximum temperature of June-September (isotherm $13.2^{\circ} \mathrm{C}$ ), while others show correlation with the tritherm (i.e. mean temperature of the three warmest months) (Aas and Faarlund 2000; Rydsaa et al. 2017). This relationship between TFLs and temperature is probably the reason why the highest TFLs commonly occur on south-facing slopes (Aas 1969; Odland 1996; Dalen and Hofgaard 2005).

In addition, studies of TFL have led to rather good understanding of the types of disturbances that control the local spatial variability of TFLs: occurrence of rock and landslides, snow avalanches and connected gusts of wind, reduced growing season in locations with long-lasting snow patches, wind, fauna, and livestock grazing (including reindeer herding and seasonal farming) (e.g. Ve 1930; Ekrheim 1935; Ve 1940; Aas 1969; Aas and Faarlund 1995; Hofgaard et al. 2009; Potthoff 2009). Moreover, the impact of edaphic and topographic conditions on the local formation and variability of TFLs through eco-physiological stress - such as caused by the availability of soil organic matter, the nutrient content and availability, soil moisture, macro- and micro-topography impacting on, for example, snow distribution, wind speed and direction, and duration and intensity of solar radiation-have been acknowledged by many authors of studies conducted in Norway (e.g. Resvoll-Holmsen 1918; Ve 1930; Ekrheim 1935; Ve 1940; Aas 1969; Rössler et al. 2008; Hofgaard et al. 2009; Wehn et al. 2012). In addition, Treter (1984) addresses the topography-related mountain mass elevation effect (Massenerhebungseffekt), which probably partly causes the high forest lines in the south-central mountain range in Norway (Fig. 1).

Lastly, rather good knowledge of where birch trees are able to establish and grow exists: in concave locations and lee sites with medium snow cover that provide protection and soil moisture, on flat ridges with less snow cover in areas with a shorter growing season, and in locations with not too dense vegetation cover, such as early-successional locations with less competition and higher soil temperatures due to sparse vegetation cover (Löffler et al. 2004; Dalen and Hofgaard 2005; Rössler et al. 2008; Hofgaard et al. 2009).

In summary, to a large extent, research on Norwegian TFL dynamics has been able to explain the importance of single factors for both broad-scale and local-scale TFL patterns. However, knowledge of interactions among disturbances, and between 
Table 3 Forest range expansion versus regrowth

\begin{tabular}{|c|c|c|c|}
\hline Data & Results & Conclusions & Reference \\
\hline $\begin{array}{l}\text { Vegetation data sampled in } \\
\text { the field }\end{array}$ & $\begin{array}{l}\text { Lack of a critical elevation for species } \\
\text { turnover }\end{array}$ & $\begin{array}{l}\text { Vegetation responses to land use most } \\
\text { likely override climatic responses }\end{array}$ & $\begin{array}{l}\text { Hofgaard } \\
\text { (1997) }\end{array}$ \\
\hline $\begin{array}{l}\text { Tree ring measurements, } \\
\text { interviews, maps, } \\
\text { photographs }\end{array}$ & $\begin{array}{l}\text { Rise of tree and forest limits during the } \\
\text { 20th century; human impact varied } \\
\text { among investigated sites; mean } \\
\text { temperatures for four warmest months } \\
\text { increased }\end{array}$ & $\begin{array}{l}\text { Relevance of land use change versus } \\
\text { climate change varies among sites }\end{array}$ & $\begin{array}{l}\text { Aschwanden } \\
\text { (2002) }\end{array}$ \\
\hline Aerial photographs & $\begin{array}{l}\text { Increase in forest cover; summer } \\
\text { temperatures increased; grazing } \\
\text { pressure decreased }\end{array}$ & Changes are caused by climate changes & $\begin{array}{l}\text { Engum } \\
\quad(2006)\end{array}$ \\
\hline Aerial photographs & $\begin{array}{l}\text { Increase in forest patches and single trees } \\
\text { in the treeline zone; no significant } \\
\text { increase in summer temperatures; } \\
\text { increased winter temperatures did not } \\
\text { extend growing season }\end{array}$ & $\begin{array}{l}\text { Changes are a consequence of land use } \\
\text { changes }\end{array}$ & $\begin{array}{l}\text { Rössler et al. } \\
\text { (2008) }\end{array}$ \\
\hline $\begin{array}{l}\text { Aerial photographs; tree } \\
\text { height growth } \\
\text { measurements }\end{array}$ & $\begin{array}{l}\text { Rising forest line and expansion of } \\
\text { mountain birch forest; vegetation } \\
\text { changes occurred below the climatic } \\
\text { forest limit; summer temperatures and } \\
\text { height growth of trees reflected low } \\
\text { potential for forest growth }\end{array}$ & $\begin{array}{l}\text { Land-use changes are the most important } \\
\text { drivers for changes }\end{array}$ & Bryn (2008) \\
\hline $\begin{array}{l}\text { Growth parameters of birch } \\
\text { saplings after a } 10 \text {-year } \\
\text { treatment experiment }\end{array}$ & $\begin{array}{l}\text { Lack of response to warming treatment; } \\
\text { grazing had a strong controlling effect }\end{array}$ & $\begin{array}{l}\text { Grazing can suppress a potential effect of } \\
\text { climate warming }\end{array}$ & $\begin{array}{l}\text { Hofgaard } \\
\text { et al. } \\
(2010)^{\mathrm{a}}\end{array}$ \\
\hline $\begin{array}{l}\text { Aerial photographs, land } \\
\text { use, biotic and abiotic } \\
\text { explanatory variables }\end{array}$ & $\begin{array}{l}\text { Rather low mean rise in the forest line; } \\
\text { changes in grazing pressure an } \\
\text { important driver for forest line changes; } \\
\text { no significant increase in regional } \\
\text { climate }\end{array}$ & $\begin{array}{l}\text { Changes in the forest line are caused by } \\
\text { changes in land use. }\end{array}$ & $\begin{array}{l}\text { Wehn et al. } \\
\text { (2012) }\end{array}$ \\
\hline $\begin{array}{l}\text { Remapped historical tree } \\
\text { and forest line data, data } \\
\text { on livestock grazing, } \\
\text { climate data }\end{array}$ & $\begin{array}{l}\text { Mainly tree and forest lines rose but also } \\
\text { stability and regression; increase in } \\
\text { temperatures and length of growing } \\
\text { season; spatial variability in changes in } \\
\text { livestock density }\end{array}$ & $\begin{array}{l}\text { Changes in tree and forest lines are } \\
\text { mainly caused by climate change; } \\
\text { reindeer grazing may have an impact on } \\
\text { changes in tree lines }\end{array}$ & $\begin{array}{l}\text { (Normark } \\
\text { 2012) }\end{array}$ \\
\hline
\end{tabular}

${ }^{a}$ The study does not explicitly focus on change, but deals with the question regarding the importance of land use versus climate

disturbances and topographic and edaphic conditions is more limited.

\section{The role of climate versus land use}

A recurrent topic when trying to explain TFL changes is the role of climate change, specifically temperature, which refers to changes that reflect a range expansion or retraction, compared with the role of local land use, which causes disturbance [i.e. changes that reflect either local regrowth or deforestation] (Table 3). Aas (1969) and Aas and Faarlund (1995) explain rising FLs as due to increased summer temperatures, yet Ve
(1951) and Aas (1969) remark that the effects of improved climate and reduced land-use intensity are difficult to separate.

As a general trend, temperatures in Norway have increased since at least the mid-1700 s (Linderholm et al. 2015). Between the end of the $1910 \mathrm{~s}$ and 1930 , all regions in Norway, with the exception of North Norway, experienced a period of cool summer temperatures (NRK and Meteorologisk institutt 2017) (see also Fig. 2). Between 1907 and 1939, the number of seasonal farms in use declined by nearly 14,000 , thus following a strong trend in decline that probably started in the mid-1800 s (Reinton 1961; Statistics 
Norway 2017) and resulting in less grazing pressure and use of firewood (Potthoff 2009). Additionally, the numbers of goats declined (Statistics Norway 2017), which is significant because goats typically grazed in the mountains and were effective in hampering forest regrowth. By contrast, the numbers of sheep and cattle increased (Statistics Norway 2017), but the increases in the amount of milk processed in local dairies rather than on the seasonal farms made it more common for dairy cows to be kept close to the main farms (Almås 2004). If the time lag in elevational tree response, and especially forest response, to climate changes are taken into account, both increased temperatures and the decline in land-use intensity have most likely contributed to the increasing tendency for rising TFLs that is reflected in the results of the two surveys conducted in the 1920s and 1930s, respectively.

The cool period that lasted until 1930 was, until the 1950 s, followed by summer temperatures that were considerably above the average for the last normal period 1961-1990 (NRK and Meteorologisk institutt 2017) (see also Fig. 2). Between the 1950s and the 1990s the summer temperatures varied around the average, with warmer and cooler periods. However, neither a similar cold period as before the 1930s nor a similar warm period as between the 1930s and 1950s was repeated until the 1990s. From the 1990s, the temperatures increased strongly. The number of seasonal farms continued decline after the 1940s and grazing pressure on unimproved land declined too (Austrheim et al. 2011; Trötscher and Hundere 2015). Thus, both improved temperatures and reduced landuse intensity have most likely contributed to the trend in rising TFLs.

Several case studies explicitly discuss the question of the role of climate versus land use in TFL changes in the second half of the 20th century (Table 3). With the exception of Engum (2006) and Normark (2012), the authors of the studies argue for the overriding importance of reduced land use and hence local regrowth. Furthermore, the intensity of land-use impacts may vary regionally as well as locally, thus resulting in deviations in the importance of climate versus land use. For example, both Wehn et al. (2012) and Aschwanden (2002) found that the relevance of the two factors varied among their investigated sites. In Normark's study (2012), the reported historical numbers of sheep $\left(1.8 \mathrm{sheep} / \mathrm{km}^{2}\right)$ and current numbers of sheep $\left(4.3 \mathrm{sheep} / \mathrm{km}^{2}\right)$ are clearly below the ratio of 10 sheep $/ \mathrm{km}^{2}$ that Speed et al. (2010) consider a low density. Thus, the intensity of the sheep grazing might not have had a significant impact on the TFLs in Normark's (2012) study area.

In summary, the available data is limited regarding the ability to explain TFL changes. For selected locations for which both detailed land-use history and local climate data are available, it is possible to assess the importance of land use versus climate for temporal TFL changes. However, for many locations in the mountains, such an assessment would be difficult, due the lack of elevational change data and detailed landuse history data. Moreover, due to a lack of data, we are not able to explain the early regional differences reflected in the two surveys, as well as potential later regional patterns.

\section{Discussion}

Treeline and forest line dynamics

Observed elevational changes in TFLs in Norway since the 1920s are similar to those identified for other European mountain areas, which are mainly TFL rises and seedlings and/or saplings occurring higher up than mature trees, but also some stability and even regression (Vittoz et al. 2008; Lenoir et al. 2009; Öberg and Kullman 2012; Cudlín et al. 2017). This is in accordance with global patterns of c.50\% rise and c.50\% stability in treelines, while regression rarely occurs (Harsch et al. 2009). An important finding is the occurrence of regional differences in the survey data, differences that still occur today. A recent study of mountain birch recruitment at the treeline showed that the recruitment peaks in central Norway, northern Sweden, and northern Norway differed (Dalen and Hofgaard 2005). Moreover, age distribution in the two southernmost study areas reflects a rather stable (possibly progressive) treeline, while indicating a recessive treeline in the north. Such regional differences are also apparent in other European treeline ecotones (Wielgolaski et al. 2017).

The reviewed material on changes in forest lines and, to a more limited degree, in treelines allow for a broad overview of elevational changes in TFLs in Norway. However, the limited data availability, limited possibilities to assess data quality, and differing definitions of TFLs mean it would be unwise to 
aggregate the scattered data into precise numbers of elevational change, such as average or maximum elevational change for Norway as a whole (e.g. Kullman and Öberg 2009), whether for the entire period since the beginning of the 20th century or for shorter periods. Similarly, data quality is often too low and data coverage is too sparse, in both time and space, to allow reliable temporal or spatial modelling of changes.

Furthermore, care needs to be taken when drawing conclusions about the endurance of TFL changes. So far, the maximum period covered by the data is c.100 years. Taking into consideration that the maximum age of a birch tree is between c.100 and c. 150 years, although older specimens have been found (Schweingruber 1993; Holtmeier et al. 2003), a change in treeline elevation and particularly in forest line elevation measured within less than c. 100 years would not allow for a final conclusion about the permanency of a measured change. Thus, changes observed so far may reflect internal population dynamics and not responses to, for example, climatic changes. An even longer period needs to be considered when taking into account the possibility that TFL responses to climate change in the short term may be strongly influenced by processes resulting in distributional time lags (Rannow 2013).

Challenges to explaining temporal and spatial patterns of elevational treeline and forest line dynamics

\section{The impact of land use}

A number of proximate drivers (e.g. temperature, precipitation, and disturbances) and ultimate (ecophysiological) drivers have an impact on TFL location. As in other mountain regions of the world (Price 2007), the long traditions of land use of the borealalpine ecotone (Ross et al. 2016) have made livestock grazing a disturbance regime of central importance in Norway. Even today, changes in TFLs in Norway are still retarded by ongoing domestic grazing (Speed et al. 2010). Compared with coniferous TFLs, TFLs dominated by birch may be particularly exposed to grazing. In contrast to, for example, Norway spruce (Picea abies), mountain birch is browsed by semidomestic animals (i.e. reindeer) and domestic animals (e.g. sheep) (Speed et al. 2010; Wehn et al. 2012).
Locations that are not affected by any type of land use will be difficult to reveal, and climatic TFLs will probably only have remained at inaccessible locations in Norway.

Despite the apparent relevance of grazing regimes for TFL dynamics, some Norwegian studies give an assessment of the importance of local land use versus climate, but few studies identify the relative importance of their impact (but see de Wit et al. 2014 for an exception). This applies also to studies of other European mountain areas, although several of them underline the importance of land-use abandonment for ongoing TFL changes (Gehrig-Fasel et al. 2007; Garbarino et al. 2013).

\section{Feedback mechanisms and interactions}

As this review shows, extensive knowledge has been accumulated of factors that have an impact on the location and changes of TFLs in Norway but also in neighbouring countries (Holtmeier et al. 2003; Broll et al. 2007; Kullman and Öberg 2009; Öberg and Kullman 2012). However, knowledge about feedback mechanisms and complex interactions among different drivers, especially in the light of climate change, is rather restricted which has also been underlined by Moen et al. (2008). However, see, for example, Holtmeir and Broll (2017) on the feedback effects of tree groups on treeline environments that include treeline ecotones in Northern Fennoscandia.

Air temperature, precipitation patterns, and wind speed-all of which are predicted to change-are variables relevant for future TFL dynamics (HanssenBauer et al. 2015). However, a single climate variable may interact with other climate variables, disturbances (e.g. increase their frequency), and edaphic and topographic conditions. More knowledge of how climate change can influence these interactions is crucial for understanding and predicting future TFLs dynamics.

For example, besides seasonal deviations during winter and summer (see Kullman 2014b for the impact of cooling on birch), seasonal displacements are to be expected in Fennoscandia (Høgda et al. 2013). Some studies have focused on the recent prolongation of the summer season in northern Europe (Shutova et al. 2006). The effects of changes in the duration of seasons on mountain birch TFL dynamics, also considering that TFLs will most likely react 
differently to climate change, have not been investigated so far. A variety of important life-cycle processes, such as the onset of bud burst or delayed winter hardening, may be impacted by such changes (Nordli et al. 2008; Poikolainen et al. 2016) and thus influence tree establishment and growth. Since climatic feedback of higher spring temperatures probably will amplify local temperature rise (Rydsaa et al. 2017), we suspect that prolonged growth seasons will contribute to a general, but small rise in the birch TFLs, unless also late frost events or other adverse conditions increase in frequency and/or intensity.

Moreover, climate change may have an impact on tree species composition along the TFLs. The factors controlling tree establishment, growth and survival along the deciduous mountain birch TFLs of the Nordic countries are similar to those controlling evergreen coniferous TFLs (Moen et al. 2008; Körner 2012; Cudlín et al. 2017). However, the eco-physiological limits differ among the species making up the TFLs. Of the available TFL species in Scandinaviamountain birch, Norway spruce, and Scots pine (Pinus sylvestris)—-mountain birch TFLs entirely dominate in the western part, whereas evergreen coniferous trees gradually substitute the deciduous TFLs farther east, in more continental climates. The most important plant functional trait regulating the differences in TFL elevation among deciduous and evergreen coniferous trees is most likely the autumn shedding of leaves by deciduous trees. Shedding their leaves makes them less prone to winter photosynthesis and subsequent water stress (i.e. drought). Studies have shown that evergreen coniferous trees, such as spruce and pine, can up-regulate photosynthesis and transpire during brief warm winter periods (Owston et al. 1972; Sevanto et al. 2006). This will increase the risk of winter and spring desiccation in regions with a maritime climate, such as western Scandinavia, with frequent warm periods during wintertime. Thus, milder winters with frequent intervals of warmer periods $\left(>0{ }^{\circ} \mathrm{C}\right)$ will most likely be advantageous for mountain birch.

Data and knowledge needed

\section{Remapping, monitoring and remote sensing}

Scarce data on FL and especially TL changes, and rather short temporal scales covered show the need of acquiring more empirical data on TFL changes. Thus, to improve the understanding of TFL dynamics, especially long-term changes and time lags, we propose systematic remapping of previous TFL studies that have not yet been resampled. The studies by, for example, Resvoll-Holmsen (1914, 1918), Ekrheim (1935), Ve (1930, 1940), and Aas (1969) all have rather good spatial precision and clear definitions of their respective TFL targets, which would enable precise estimations of previous changes if remapped. The oldest of these publications already allows for the investigation of changes within a 100-year time perspective. The collection of tree age data should be included as part of the remapping because these data would provide important supplemental information with which to access the permanency of TFL changes (Treter 1984).

Repeated mapping only provides temporal snapshots and should therefore be supplemented by systematic monitoring of TFLs (e.g. Kullman 2014a). Treelines should receive special attention, since the current lack of data on treeline dynamics hampers the understanding of several important aspects of TFL dynamics, such as dispersal and disturbance. Indications of expansion divergence among forest, tree, and species lines (Kullman 2010) mirror the fact that these lines respond idiosyncratically to environmental change. Treelines that respond more quickly to environmental changes than forest lines can be important preliminary indicators for subsequent changes in forest line elevation. For monitoring purposes, TFLs positioned either at elevations or on mountains too low to support previous and future climatic TFLs' dynamics should be disregarded (Aas 1969; Odland 2015).

To identify the effects of climate change, grazing, and other correlated drivers that are the cause of TFLs' dynamics, the monitoring should include a full factorial field design that also captures Norways large natural variation. Combining the monitoring approach with field experiments would provide further possibilities to access the relevance of different factors (see e.g. Speed et al. 2010). Further experiments that address the ultimate drivers of TFL dynamics, although not in focus of this review, should preferably cover, for example, in situ chamber experiments (e.g. Hofgaard et al. 2010), relocation experiments, or laboratory experiments (e.g. Lett et al. 2016). 
New techniques for remote TFL mapping and modelling are constantly being developed, and fieldbased monitoring of TFL changes could be supplemented by methods that implement, for example, LiDAR/ALS or satellite data (see Ørka et al. 2012 for an example). These techniques can potentially improve some aspects of future data quality, such as locality precision (Hauglin and Næsset 2016). Furthermore, the above-mentioned methods can provide an overview of larger areas than field-based monitoring (Nyström et al. 2013), in addition to providing measures of, for example, biomass, leaf area index, albedo, plant functional types, and other relevant descriptors that can improve the understanding and modelling of TFL dynamics.

\section{Preconditions for projective modelling of TFLs}

Statistical distribution models (DMs) or process models, such as global dynamic vegetation models (DGVMs), are frequently used to predict the potential range expansion of boreal forests, including TFLs (e.g. de Wit et al. 2014). The proposed data collection and increased understanding of ultimate and proximate drivers controlling TFL dynamics will help to improve TFL models and to avoid overestimation of predicted changes (Hofgaard et al. 2013). All models involve important premises and assumptions, and in the following we focus on two assumptions that need to be critically considered and implemented in projective models.

First, taking the comprehensive use of mountain resources in Norway into consideration, it is timely to question the assumption that the present positions of TFLs can be taken as indicators of the present climate. Thus, for modelling the impact of climate changes on TFLs, only training data (TFL positions) that are not influenced by disturbances, such as domestic grazing, should be used. An alternative approach, tested by Bryn (2008) and de Wit et al. (2014), is to first model the effect of domestic grazing or other land-use processes, and then estimate the effect of climate changes alone. This is usually done by implementing potential natural vegetation maps as a reference baseline for modelling (e.g. Koca et al. 2006). Alternatively, it can be done by implementing a null model of TFLs in which the effect of land use is removed (Bryn et al. 2013). However, the precondition of identifying training sites that represent undisturbed natural vegetation remains. Thus, besides identifying the relative importance of different proximate drivers, it still remains to be tested whether and where locations with no disturbance or the least likelihood of disturbance can be found. In addition, past, current, and future disturbances need to be incorporated in model development.

Second, an important precondition for using climatic variables that represent previous periods for modelling of temporal changes is a static climatic response (niche conservatism) among TFL species. However, recent research indicates that some tree species have changed their climatic tolerance during the Holocene (Cheddadi et al. 2016). This precondition, whether implemented for decades or within a century, is probably irrelevant (Peterson 2011). However, the earliest data available for remapping are just about to allow for covering changes over a period of about 100 years. Thus, long-term (i.e. the entire Holocene) studies of TFL dynamics, testing specifically the niche conservatism of mountain birch, seem relevant for projective modelling beyond the next few centuries (e.g. de Wit et al. 2014).

To summarize our discussion, according to our understanding, three main domains should be emphasized for future TFL research in Norway: (1) improve the empirical basis of TFLs' dynamics and contribute to a better understanding of the relevance of proximate and ultimate drivers, (2) improve the understanding of interactions and feedback mechanisms among different drivers, (3) provide a better understanding of the preconditions and empirical basis for projective modelling (sensu lato). Although addressed for mountain birch in Norway, we consider these research domains equally relevant for mountain regions outside Scandinavia, with other TFL-forming species, especially where the empirical bases for understanding of TFL changes are fragmentary or unreliable (Malanson et al. 2011).

\section{Conclusions}

The existing data provide a broad overview of elevational TFL changes. Although the reviewed material is too scattered and varied to enable estimations of precise numbers of TFL changes for Norway as a whole, the main trend is a rise in TFLs since the 1920s. Disturbances, site conditions, and dispersal and 
survival processes may slow down the potential elevational TFL dynamics that could be expected as a consequence of climate change.

To improve future empirically-based predictions of TFL dynamics, a better understanding of ongoing dynamics, the role of proximate and ultimate drivers, and especially interactions and feedback among them is needed. To close the knowledge gap, we propose a combination of increased remapping of previously mapped TFLs, monitoring of TFLs, and field and laboratory experiments. Before field-based monitoring approaches are established and endure long enough for researchers to provide reliable estimates of TFL changes, more research efforts should be directed towards remapping previously mapped TFLs. The fact that Norway's TFLs are dominated by one species, the country's large natural variation, and its long history of land-use all make Norwegian TFL research an interesting topic for future research, with the potential to contribute to the global understanding of TFL dynamics.

Acknowledgements We thank Friedrich-Karl Holtmeier, Peter Horvath, and Frode Stordal for stimulating comments on an earlier version of the manuscript. We are also grateful for improvements suggested by the anonymous reviewers.

Open Access This article is distributed under the terms of the Creative Commons Attribution 4.0 International License (http:// creativecommons.org/licenses/by/4.0/), which permits unrestricted use, distribution, and reproduction in any medium, provided you give appropriate credit to the original author(s) and the source, provide a link to the Creative Commons license, and indicate if changes were made.

\section{References}

Aas B (1969) Climatically raised birch lines in southeastern Norway 1918-1968. Nor Geogr Tidsskr 23:119-130

Aas B, Faarlund T (1995) Skoggrenseutviklingen i Norge, særlig i det 20. århundre. AmS-Varia 24:89-100

Aas B, Faarlund T (1996) The present and the Holocene subalpine birch belt in Norway. In: Frenzel B (ed) Holocene treeline oscillations, dendrochronology and palaeoclimate. Gustav Fischer, Stuttgart, pp 19-42

Aas B, Faarlund T (2000) Forest limits and the subalpine birch belt in North Europe with a focus on Norway. AmS-Varia 37:103-147

Almås R (ed) (2004) Norwegian agricultural history. Tapir Akademisk Forlag, Trondheim

Ameztegui A, Coll L, Brotons L, Ninot JM (2016) Land-use legacies rather than climate change are driving the recent upward shift of the mountain tree line in the Pyrenees. Glob Ecol Biogeogr 25:263-273

Aschwanden S (2002) Changes in the tree- and forest-limits of Nordic mountain birch in Narvik Municipality during the 20th century. Master's thesis, Norwegian University of Science and Technology

Austrheim G, Solberg EJ, Mysterud A (2011) Spatio-temporal variation in large herbivore pressure in Norway during 1949-1999: has decreasing grazing by livestock been countered by increased browsing by cervids? Wildl Biol 17:286-298

Axelsen BJ (1975) Ressursutnyttelse i et fjellområde. Seterfjellet i Øystre Slidre - Utnyttelse av og påvirking på naturgrunnlaget. Master's thesis, Universitetet i Oslo

Broll G, Holtmeier F-K, Anschlag K, Brauckmann SW, Drees B (2007) Landscape mosaic in the treeline ecotone on Mt Rodjanoaivi, Subarctic Finland. Fennia 185:89-105

Bryn A (2008) Recent forest limit changes in south-east Norway: effects of climate change or regrowth after abandoned utilisation? Nor Geografisk Tidsskr Nor J Geogr 62:251-270

Bryn A, Daugstad K (2001) Summer farming in the subalpine birch forest. In: Wielgolaski FE (ed) Nordic Mountain Birch Ecosystems. Man and the biosphere series. UNESCO \& Parthenon, Paris, pp 307-315

Bryn A, Dourojeanni P, Hemsing L, , O’Donnel S (2013) A high-resolution GIS null model of potential forest expansion following land use changes in Norway. Scand J For Res 28:81-98

Bryn A, Potthoff K (2017) 20th century Betula pubescens subsp. czerepanovii tree- and forest lines in Norway. Biodivers. Data J 5:e22093

Case BS, Duncan RP (2014) A novel framework for disentangling the scale-dependent influences of abiotic factors on alpine treeline position. Ecography 37:838-851

Cheddadi R, Araújo MB, Maiorano L, Edwards M, Guisan A, Carré M, Chevalier M, Pearman PB (2016) Temperature range shifts for three European tree species over the last 10,000 years. Front Plant Sci 7:1-13

Cudlín P, Klopčič M, Tognetti R et al (2017) Drivers of treeline shift in different European mountains. Clim Res 73:135-150

Dalen L, Hofgaard A (2005) Differential regional treeline dynamics in the Scandes Mountains. Arct Antarc Alp Res 37:284-296

de Wit HA, Bryn A, Hofgaard A, Karstensen J, Kvalevåg MM, Peters GP (2014) Climate warming feedback from mountain birch forest expansion: reduced albedo dominates carbon uptake. Glob Chang Biol 20:2344-2355

Ekrheim O (1935) Die Waldgrenzen auf der Haugesund-Halbinsel im westlichen Norwegen. Det Norske VidenskapsAkademi, Oslo

Engum H-C (2006) Alpine tre- og skoggrenseendringer. Indikator på klimaforandringer eller endret arealbruk? Master's thesis, University of Bergen

Garbarino M, Lingua E, Weisberg PJ, Bottero A, Meloni F, Motta R (2013) Land-use history and topographic gradients as driving factors of subalpine Larix decidua forests. Landscape Ecol 28:805-817

Gaston KJ (2009) Geographic range limits of species. Proc R Soc B 276:1391-1393 
Gehrig-Fasel J, Guisan A, Zimmermann NE (2007) Tree line shifts in the Swiss Alps: climate change or land abandonment? J Veg Sci 18:571-582

Hansen LI, Olsen B (2004) Samenes historie fram til 1750. Cappelen Akademisk Forlag, Oslo

Hanssen-Bauer I, Førland EJ, Haddeland I et al (eds) (2015) Klima i Norge 2100: kunnskapsgrunnlag for klimatilpasning oppdatert i 2015. Norsk klimaservicesenter, Oslo

Harsch MA, Hulme PE, McGlone MS, Duncan RP (2009) Are treelines advancing? A global meta-analysis of treeline response to climate warming. Ecol Lett 12:1040-1049

Hauglin M, Næsset E (2016) Detection and segmentation of small trees in the forest-tundra ecotone using airborne laser scanning. Remote Sens 8:407

Helland A (1912) Trægrænser og sommervarmen. Tidsskrift for skogbruk 12:131-146, 169-175, 303-313

Hesselberg T, Birkeland BJ (1940) Säkulare Schankungen des Klimas von Norwegen. 1. Teil. Die Lufttemperatur. Grøndahl \& Søn, Oslo

Hofgaard A (1997) Inter-relationships between treeline position, species diversity, land use and climate change in the central Scandes Mountains of Norway. Glob Ecol Biogeogr Lett 6:419-429

Hofgaard A, Dalen L, Hytteborn H (2009) Tree recruitment above the treeline and potential for climate-driven treeline change. J Veg Sci 20:1133-1144

Hofgaard A, Løkken JO, Dalen L, Hytteborn H (2010) Comparing warming and grazing effects on birch growth in an alpine environment - a 10-year experiment. Plant Ecol Divers 3:19-27

Hofgaard A, Tømmervik H, Rees G, Hanssen F (2013) Latitudinal forest advance in northernmost Norway since the early 20th century. J Biogeogr 40:938-949

Høgda KA, Tømmervik H, Karlsen SR (2013) Trends in the start of the growing season in Fennoscandia 1982-2011. Remote Sens 5:4304-4318

Holtmeier F-K (2009) Mountain Timberlines: ecology, patchiness, and dynamics. Springer, Berlin

Holtmeier F-K, Broll G, Müterthies A, Anschlag K (2003) Regeneration of trees in the treeline ecotone: Northern Finnish Lapland. Fennia 181:103-128

Holtmeir F-K, Broll G (2017) Feedback effects of clonal groups and tree clusters on site conditions at the treeline: implications for treeline dynamics. Clim Res 73:85-96

Jacob M, Frankl A, Beeckman H, Mesfin G, Hendrickx M, Guyassa E, Nyssen J (2015) North Ethiopian Afro-alpine tree line dynamics and forest-cover change since the early 20th century. Land Degrad Dev 26:654-664

Koca D, Smith B, Sykes M (2006) Modelling regional climate change effects on potential natural ecosystems in Sweden. Clim Chang 78:381-406

Körner C (2012) Alpine treelines. Functional Ecology of the Global High Elevation Tree Limits. Springer, Basel

Kullman L (2010) A richer, greener and smaller alpine world: review and projection of warming-induced plant cover change in the Swedish Scandes. Ambio 39:159-169

Kullman L (2014a) Treeline (Pinus sylvestris) landscape evolution in the Swedish Scandes - a 40-year demographic effort viewed in a broader temporal context. Nor Geografisk Tidsskr Nor J Geogr 68:155-167
Kullman L (2014b) Recent cooling and dynamic responses of alpine summit floras in southern Swedish Scandes. Nord J Bot 32:369-376

Kullman L, Öberg L (2009) Post-Little Ice Age tree line rise and climate warming in the Swedish Scandes: a landscape ecological perspective. J Ecol 97:415-429

Lenoir J, Gégout J-C, Pierrat J-C, Bontemps J-D, Dhôte J-F (2009) Differences between tree species seedling and adult altitudinal distribution in mountain forests during the recent warm period (1986-2006). Ecography 32:765-777

Lett S, Nilsson M-C, Wardle DA, Dorrepaal E (2016) Bryophyte traits explain climate-warming effects on tree seedling establishment. J Ecol 105:496-506

Linderholm HW, Björklund J, Seftingen K, Gunnarson BE, Fuentes M (2015) Fennoscandia revisited: a spatially improved tree-ring reconstruction of summer temperatures for the last 900 years. Clim Dyn 45:933-947

Lloyd A (2005) Ecological histories from Alaskan tree lines provide insight into future change. Ecology 86:1687-1695

Löffler J, Lundberg A, Rössler O, Bräuning A, Jung G, Pape R, Wundram D (2004) The alpine treeline under changing land use and changing climate: approach and preliminary results from continental Norway. Nor Geografisk Tidsskr Nor J Geogr 58:183-193

Malanson GP, Resler LM, Bader MY, Holtmeier F-K, Butler DR, Weiss DJ, Daniels LD, Fagre DB (2011) Mountain treelines: a roadmap for research orientation. Arct Antarc Alp Res 43:167-177

Moen J, Cairns DM, Lafon CW (2008) Factors structuring the treeline ecotone in Fennoscandia. Plant Ecol Divers $1: 77-87$

Nordli Ø, Wielgolaski FE, Bakken AK, Hjeltnes SH, Måge F, Sivle A, Skre O (2008) Regional trends for bud burst and flowering of woody plants in Norway as related to climate change. Int J Biometeorol 52:624-639

Normark K (2012) The shift in forest and tree limits in Troms County - with a main focus on temperatures and herbivores. Examensarbete i ämnet biologi, Sveriges lantbruksuniversitet

Norwegian Mapping Authority (2007) The N50 topographic map series of Norway. Scale 1:50.000. Updated in 2007. Norwegian Mapping Authority, Hønefoss

NRK \& Meteorologisk institutt (2017) Klima i Norge og verden. https://www.yr.no/klima/Accessed 28 June 2017

Nyström M, Holmgren J, Olsson H (2013) Change detection of mountain birch using multi-temporal ALS point clouds. Remote Sens Lett 4:190-199

Öberg L, Kullman L (2012) Contrasting short-term performance of mountain birch (Betula pubescens ssp. czerepanovii) treeline along a latitudinal continentality-maritimity gradient in the southern Swedish Scandes. Fennia 190:19-40

Odland A (1996) Differences in the vertical distribution pattern of Betula pubescens in Norway and its ecological significance. In: Frenzel B (ed) Holocene treeline oscillations, dendrochronology and palaeoclimate. Gustav Fischer, Stuttgart, pp 43-59

Odland A (2015) Effect of latitude and mountain height on the timberline (Betula pubescens ssp. czerepanovii) elevation along the central Scandinavian mountain range. Fennia 193:260-270 
Olsson EGA, Austrheim G, Grenne SN (2000) Landscape change patterns in mountains, land use and environmental diversity, Mid-Norway 1960-1993. Landsc Ecol 15:155-170

Ørka HO, Wulder MA, Gobakken T, Næsset E (2012) Subalpine zone delineation using LiDAR and Landsat imagery. Remote Sens Environ 119:11-20

Owston PW, Smith JL, Halverson HG (1972) Seasonal water movement in tree stems. For Sci 18:266-272

Peterson AT (2011) Ecological niche conservatism: a timestructured review of evidence. J Biogeogr 38:817-827

Poikolainen J, Tolvanen A, Karhu J, Kubin E (2016) Seventeenyear trends in spring and autumn phenophases of Betula pubescens in a boreal environment. Int $\mathrm{J}$ Biometeorol 60:1227-1236

Potthoff K (2009) Grazing history affects the tree-line ecotone: a case study from Hardanger, Western Norway. Fennia 187:81-98

Potthoff K (2017) Spatiotemporal patterns of birch regrowth in a Western Norwegian treeline ecotone. Landsc Res 42:63-77

Price M (2007) Integrated approaches to research and management in mountain areas: an introduction. In: Price $\mathbf{M}$ (ed) Mountain area research \& management. Integrated approaches. Earthscan, London, pp 1-23

Rannow S (2013) Do shifting forest limits in south-west Norway keep up with climate change? Scand J For Res 28:574-580

Reinton L (1961) Sæterbruket i Noreg III. H. Aschehoug, Oslo

Resvoll-Holmsen H (1914) Statistiske vegetationsundersøgelser fra Foldalsfjeldene. Dybwad, Oslo

Resvoll-Holmsen H (1918) Fra fjeldskogene i det östenfjeldske Norge. Tidsskr Skogbruk 26:107-223

Ross LC, Austrheim G, Asheim L-J et al (2016) Sheep grazing in the North Atlantic region: a long-term perspective on environmental sustainability. Ambio 45:551-566

Rössler O, Bräuning A, Löffler J (2008) Dynamics and driving forces of treeline fluctuation and regeneration in central Norway during the past decades. Erdkunde 62:117-128

Rydsaa JH, Stordal F, Bryn A, Tallaksen LM (2017) Effects of shrub and tree cover increase on the near-surface atmosphere in northern Fennoscandia. Biogeosciences 14:4209-4227

Rydsaa JH, Stordal F, Tallaksen LM (2015) Sensitivity of the regional European boreal climate to changes in surface properties resulting from structural vegetation perturbations. Biogeosciences 12:3071-3087

Schweingruber FH (1993) Trees and wood in dendrochronology: morphological, anatomical, and tree-ring analytical characteristics of trees frequently used in dendrochronology. Springer, Berlin

Sevanto S, Suni T, Pumpanen J, Grönholm T, Kolari P, Nikinmaa E, Hari P, Vesala T (2006) Wintertime photosynthesis and water uptake in a boreal forest. Tree Physiol 26:747-757

Sharma LN, Vetaas OR, Chaudhary RP, Måren IE (2014) Pastoral abandonment, shrub proliferation and landscape changes: a case study from Gorkha, Nepal. Landsc Res 39:53-69

Shutova E, Wielgolaski FE, Karlsen SR et al (2006) Growing seasons of Nordic mountain birch in northernmost Europe as indicated by long-term field studies and analyses of satellite images. Int J Biometeorol 51:155-166

Smith WK, Germino MJ, Johnson DM, Reinhardt K (2009) The altitude of alpine treeline: a bellwether of climate change effects. Bot Rev 75:163-190

Speed JDM, Austrheim G, Hester AJ, Mysterud A (2010) Experimental evidence for herbivore limitation of the treeline. Ecology 91:3414-3420

Statistics Norway (2017) Historiske landbruksteljingar (19071999). https://www.ssb.no/a/histstat/landbrukstellinger. html Accessed 28 June 2017

Treter U (1984) Die Baumgrenzen Skandinaviens. Franz Steiner, Wiesbaden

Trötscher TA, Hundere GCT (2015) Tematisk gjennomgang av miljøstatus og verkemiddelbruk. Landbruksdirektoratet, Oslo

Ve S (1930) Skogtrærnes forekomst og høidegrenser i Årdal. Plantegeografiske og bygdehistoriske studier. A. S. John Griegs Boktrykkeri, Bergen

Ve S (1940) Skog og treslag i Indre Sogn frå Lærdal til Fillefjell. Med ei utgreiding um gran i Sogn. Vestlandets forstlige fors $\varnothing$ ksstation, Bergen

Ve S (1951) Stig skoggrensa? Tidsskr Skogbruk 59:305-317

Vittoz P, Rulence B, Largey T, Freléchoux F (2008) Effects of climate and land-use change on the establishment and growth of cembran pine (Pinus cembra L.) over the altitudinal treeline ecotone in the Central Swiss Alps. Arct Antarc Alp Res 40:225-232

Wehn S, Olsson G, Hanssen S (2012) Forest line changes after 1960 in a Norwegian mountain region - implications for the future. Nor Geografisk Tidsskr Nor J Geogr 66:2-10

White PS, Pickett STA (1985) Natural disturbance and patch dynamics: an introduction. In: Pickett STA, White PS (eds) The ecology of natural disturbance and patch dynamics. Academic Press, San Diego, pp 3-13

Wielgolaski FE, Hofgaard A, Holtmeier FK (2017) Sensitivity to environmental change of the treeline ecotone and its associated biodiversity of European mountains. Clim Res 73:151-166

Wullschleger SD, Epstein HE, Box EO et al (2016) Plant functional types in Earth system models: past experiences and future directions for application of dynamic vegetation models in high-latitude ecosystems. Ann Bot 114:1-16 